Historical Geography

Elsevier Editorial System(tm) for Journal of

Manuscript Draft

Manuscript Number: JHGE14-94R1

Title: GEOGRAPHIES OF COMMEMORATION: ANGEL ISLAND, SAN FRANCISCO AND NORTH HEAD, SYDNEY

Article Type: Full Length Article

Keywords: Commemoration; Immigration; Inscriptions; Memorialisation; Quarantine; Graffiti

Corresponding Author: Prof. Alison Bashford, PhD

Corresponding Author's Institution: University of Cambridge

First Author: Alison Bashford, PhD

Order of Authors: Alison Bashford, PhD; Peter Hobbins, PhD; Anne Clarke, PhD; Ursula Frederick, PhD

Abstract: Memorialising lives, deaths, and events in landscapes can be authorised, official, and highly regulated, or spontaneous, unsanctioned, and anti-authoritarian. Interpreting and connecting two sites spanning the Pacific Ocean, this paper explores the inscribed and affective landscapes of Angel Island, San Francisco, and North Head, Sydney. Both sites encompass multivalent histories of defence, quarantine, immigration and leisure. Both also host a continuum of mark-making practices, from informal graffiti to monuments aspiring to direct national narratives. Elaborating the rich and complex layering of histories at each site, we trace the semiotic and emotive circuits traced by their endorsed and vernacular inscriptions. In particular, we question the work done when individual or even surreptitious texts are appropriated - or marketed within formal narratives of inclusiveness, reverence and homogeneous nationalism. Drawing upon scholarship from archaeology, history, geography and heritage studies, this analysis argues that formalised commemoration never escapes the potential for counter-readings - that authority and authorship never entirely coincide. 
Faculty of History

Alison Bashford

Vere Harmsworth Professor of Imperial History Fellow, Jesus College

Professor Christian Brannstrom and Professor Miles Ogburn, Editors, Journal of Historical Geography

Dear Professors Brannstrom and Ogburn,

Please accept the submission of my co-authored article, 'Geographies of Commemoration: Angel Island, San Francisco and North Head, Sydney'.

I look forward to your response, in due course.

Yours sincerely

Alison Bashford

Vere Harmsworth Professor of Imperial History

1 October 2014 
Thank you once again for the opportunity to re-submit our paper, 'Geographies of commemoration', to the Journal of Historical Geography. We apologies for the length of time taken to coordinate the response from our authorial team, but we are now pleased to submit what we believe is a much stronger and more appropriately targeted manuscript.

As the referees' comments were quite diverse, we have grouped our responses to their comments and your overall assessment - in the sections below.

Introduction

The opening section of the paper is now much more detailed, as we have sought to engage with a wide variety of contemporary cultural geography and heritage studies scholarship. We much appreciated the many literature suggestions made by the reviewers and although we have not referred to all of their recommended works, they were a valuable launching point. We believe that the introduction now more firmly specifies our interpretive methodology. In particular, we foreground the value of attending to the complexities of inscription in both the heritage and 'dark tourism' context, including its affective valences.

\section{Structure}

The paper now moves more straightforwardly from the introduction to the historical background of both sites, before progressing to an analysis of one aspect of Angel Island and another at North Head. We hope that this format overcomes concerns about the complex construction of our initial submission. There is now also a more consistent analytical thread running through the ms, viz. the tension between authorship and authority which plays out in multiple scales, sites and practices. We now also believe that the stylistic variations between sections have been smoothed.

\section{Defence and Holocaust material}

In order to simplify the paper, we have largely omitted mention of war memorialisation at the North Head site, and thus largely removed anything other than historical references to defence. Aware of both the delicacy and complexity of Holocaust scholarship, coupled with a re-assessment of our own case material, we have reduced direct comparisons between immigration monuments and Holocaust memorials. This issue remains relevant, as noted in several places, but we agree that the two formats perform different political and emotional work.

\section{Affect and visitor experience}

We have questioned our tourism/heritage contacts at both Angel Island and North Head, and unfortunately there is nothing but anecdotal evidence regarding visitor experiences and perspectives. We have therefore toned down our presumption of how visitors might encounter the material, adopting a more subjective approach to interpreting the semiotic and affective implications. Acknowledging that there is a large literature on affect and geography, we have drawn upon selected sources to nuance our use of the term.

Once again, we thank you for your forbearance and for the opportunity to re-submit our paper to the Journal; we hope that our revised efforts are now more suitable. 


\section{GEOGRAPHIES OF COMMEMORATION:}

\section{ANGEL ISLAND, SAN FRANCISCO AND NORTH HEAD, SYDNEY}

\section{Corresponding author:}

Professor Alison Bashford

Vere Harmsworth Professor of Imperial and Naval History, Faculty of History, University of

Cambridge

acb90@cam.ac.uk

Jesus College, Cambridge, CB5 8BL, UK

\section{Co-authors:}

Dr Peter Hobbins

Department of History, University of Sydney

peter.hobbins@sydney.edu.au

Room 707, Brennan MacCallum A18, University of Sydney, NSW 2006, Australia

Dr Anne Clarke

Department of Archaeology and Heritage Studies, University of Sydney

annie.clarke@sydney.edu.au

Room J409, The Quadrangle A14, University of Sydney, NSW 2006, Australia

Dr Ursula K Frederick

Department of Archaeology, University of Sydney

ursula.frederick@sydney.edu.au

C/- Room J409, The Quadrangle A14, University of Sydney, NSW 2006, Australia 


\section{Highlights}

- Defence, quarantine, immigration, and leisure often overlap at historic sites.

- This paper compares formal and vernacular inscriptions at two Pacific Rim sites.

- Endorsed and vernacular inscriptions often trace semiotic and emotive circuits.

- We question the work done when formal narratives appropriate individual texts.

- Whether in graffiti or monuments, authority and authorship never entirely coincide. 


\title{
GEOGRAPHIES OF COMMEMORATION:
}

\section{ANGEL ISLAND, SAN FRANCISCO AND NORTH HEAD, SYDNEY}

\begin{abstract}
:
Memorialising lives, deaths, and events in landscapes can be authorised, official, and highly regulated, or spontaneous, unsanctioned, and anti-authoritarian. Interpreting and connecting two sites spanning the Pacific Ocean, this paper explores the inscribed and affective landscapes of Angel Island, San Francisco, and North Head, Sydney. Both sites encompass multivalent histories of defence, quarantine, immigration and leisure. Both also host a continuum of mark-making practices, from informal graffiti to monuments aspiring to direct national narratives. Elaborating the rich and complex layering of histories at each site, we trace the semiotic and emotive circuits traced by their endorsed and vernacular inscriptions. In particular, we question the work done when individual or even surreptitious texts are appropriated - or marketed - within formal narratives of inclusiveness, reverence and homogeneous nationalism. Drawing upon scholarship from archaeology, history, geography and heritage studies, this analysis argues that formalised commemoration never escapes the potential for counter-readings - that authority and authorship never entirely coincide.
\end{abstract}

\section{Keywords:}

Commemoration

Immigration

Inscriptions

Memorialisation 
Quarantine

Graffiti

Running headline:

Geographies of commemoration 
The historical geography of memorialising and commemoration operates across a continuum, from highly orchestrated state endeavours to intensely private individual mark-making practices. At one end lie military and Holocaust memorials, at the other end quotidian graffiti. ${ }^{1}$ Somewhere in between reside monuments to the dead: cemeteries, headstones, and plaques that have their own complex histories and practices of formal design and semiotic arrangement. ${ }^{2}$ The memorialising of lives, deaths, and events in landscapes can be authorised, official, and highly regulated, or spontaneous, unauthorised, and even anti-authoritarian. Much memorialising, nevertheless, combines public display with an ambition toward interior reflection, aiming for - and often achieving - an affective response. ${ }^{3}$

In recent years, geographers have joined tourism and heritage scholars in turning away from interrogating formal, sanctioned monuments in favour of vernacular practices and the memory work they perform. Such studies encompass nominally 'incidental' graffiti, ephemeral shrines, the deviation of docents from history-tour scripts and the individuated expectations that consumers place upon - and perform at - heritage sites. ${ }^{4}$ Operating against or beyond authorised arenas of memory, such interventions may contribute to an antithetical accretion of symbols within memorial landscapes. Conversely, they may project territorial claims of cultural or racial 'heritage' onto otherwise unremarkable streets, neighbourhoods or villages. ${ }^{5}$ Geographer Hamzah Muzaini has powerfully demonstrated how individuals and cultural groups may seek to maintain their ontological security precisely via nonengagement with formal memorials, through productive acts of forgetting or by dispersing their past into personal memories, family stories and domestic artefacts. ${ }^{6}$ Whether pursued for counter-hegemonic or consumerist ends, this democratisation represents a historical re-scaling of the politics of memorialising 
practices. ${ }^{7}$ As Reuben Rose-Redwood and Laurajane Smith remind us, attending to these intimate and highly localised interventions can be revealing of the emotional microeconomics of investing memory in public places and traces. ${ }^{8}$ Such encounters can be heightened, as Karen Till's work has shown, at historically 'wounded' sites, 'haunted locales through which unfolding and intersecting social and personal histories resonate across space and time'. ${ }^{9}$ Indeed, this paper is animated by the dialectic between the creation and consumption of 'heritage' at two sites where official commemoration and individualised mark-making come together in highly dense assemblages.

Angel Island in San Francisco and North Head in Sydney are two coastal sites - respectively insular and peninsular - on either side of the Pacific Ocean. As entry points to continental territories and (therefore) to national histories, they have comparable pasts as quarantine stations, places of immigration detention and of military defence. Angel Island and North Head also share comparable presents as sites of heritage tourism, whose public draw and affective impact rests in part on their stunning landscapes proximate to major cities. A further appeal, however, lies in their dark pasts, which are actively commemorated by the authorities responsible for their twenty-first century management. While there have been numerous studies that address the rich and connected quarantine-military-immigration-leisure use of these particular coastal sites, none compare and link these two Pacific landscapes. ${ }^{10}$

Historically, it has been commonplace to observe geographic overlays of military defence, protection against infectious diseases configured as invasive, and immigration configured as a threatening contamination. The structures, processes and purposes of health, immigration, and defence coincided at sites along almost any 
border one cares to examine, whether terrestrial (for example, the Mexico-US border) or maritime (for example, Victoria, British Columbia or Robben Island, South Africa). ${ }^{11}$ Owing to their multivalent pasts, Angel Island and North Head likewise occupy complex and competing locations in the spectrum of 'dark tourism' sites. Functioning simultaneously as places of civil imprisonment, military defence and 'benevolent internment', both their product offering and visitor expectations slide across a range of dark heritage typologies, amongst more quotidian leisure activities. ${ }^{12}$ Here we are less concerned with the intertwined past uses of these places of complex isolation and segregation, and more with the interwoven practices of markmaking and commemoration that they have elicited. Angel Island and North Head are both populated with extensive assemblages of informal and personal inscriptions, paintings, carvings, and graffiti that have themselves come to form part of the heritage and historical pedagogy of national remembering. From graffiti to sanctioned inscriptions, headstones to war memorials, they prove concentrated spaces of formal and informal, authorised and unauthorised mark-making; landscapes of affective commemoration.

Conceptualising these markers as 'materialized discourses emplaced in the landscape' is critical to interpreting their historical dynamics of meaning.${ }^{13}$ As Laura McAtackney has argued of political murals in Northern Ireland, 'the walls on which murals are placed often dictate the nature of their subject matter and the timescales on which they will be allowed to survive'. ${ }^{14}$ If those walls themselves both restrict and define the communities they enclose, they also provide a forum for the endless dialogue between shifting patterns of murals and graffiti.

In this sense, we interpret the memorial landscapes of North Head and Angel Island not simply as assemblages of texts or layered narratives, but as strategically 
sited arenas which 'seek to influence collective decisions or policies, justify their claims to the past, and entice others to participate in the debate'. ${ }^{15}$ In effect, they comprise a community of inscriptions - emerging, conversing, shaping each other's position and meaning, fading from visibility or importance, occasionally resurrected from obscurity. The inscriptions likewise participate in a politics of scale: if each carved line or whorl reminds us of the intimate efforts of its creator, their messages evoke the names of individuals, ships and nations, gesturing all at once to intensely local affiliations and global mobilities. ${ }^{16}$ Thus to 'read' these inscriptions requires attending not only to their content, technique, medium and placement, but also to historical changes in their institutional contexts.

In this paper we examine a selection of these multi-temporal formal and informal commemorative marks. ${ }^{17}$ First, we analyse the individualised historical inscriptions made by those detained under quarantine and immigration regulations. Second, we trace the relationships between these personal - if sometimes complex marking and the highly designed, state-orchestrated landscapes of commemoration that tell purportedly foundational national narratives. The affective impact of oncepersonal inscriptions is purposefully redeployed both in the past - where pre-existing inscriptions may have prompted others to follow suit - and in the present, where they work as memorials to those who passed through. We then pursue these formal commemorations back into informal and unauthorised registers, analysing their sequence, repetition, and reappearance as graffiti.

These two 'new world' sites richly contribute to our understanding of the entanglement of subjectivity and national identity, memory-making and markmaking. The 'homelands' often studied in European landscapes - particularly in England and Germany - comprise territorial sites to be marked, commemorated, and 
claimed as places of unambiguous belonging, as Simon Schama and others have argued. ${ }^{18}$ Such wistful nationalisms have been described as 'topophilia', encompassing 'local landscapes marked by time, places where the past is tangible' ${ }^{19}$ For non-Indigenous colonial-settler societies, by contrast, Angel Island and North Head were liminal sites on the very edges of 'homelands' that were only aspirational. This memory-and-mark-making was undertaken by newcomers who had highly precarious attachments to these new lands, but into which they nonetheless assertively carved themselves a place.

\section{INSCRIBING PRESENCE IN PACIFIC LANDSCAPES: ANGEL ISLAND}

\section{AND NORTH HEAD}

San Francisco and Sydney are often popularly compared as two coastal cities, their magnificent harbours serving as gateways between the Pacific Ocean and vast terrestrial spaces. Historians and geographers link them too, as nineteenth-century coastal frontier settlements that became key regional entrepôts. By the fin de siècle, however, their multicultural communities came to be increasingly regulated by national measures that restricted maritime ingress and egress into ever more firmly bounded national spaces.

As transpacific towns, their substantive historical connections have also been richly traced. ${ }^{20}$ Simultaneous mid nineteenth-century gold rushes meant that thousands of fortune-seekers travelled diagonally across the Pacific. Thousands more travelled a triangulated route between the Californian goldfields, the Australian goldfields, and Chinese ports. The presence of Chinese gold-seekers in territories deemed white prompted the earliest round of race-based immigration restriction laws 
in the 1850 s, regulations that were to reappear in wider form in the 1880 s, and to consolidate and harden early in the twentieth century. ${ }^{21}$

One of the growing rationales for exclusion and restriction was disease, and many scholars have detailed the way in which Chinese people, in particular, have been subject to specific laws, practices, and restrictions in this regard. ${ }^{22}$ Quarantine and immigration restriction worked hand-in-glove in multiple new world contexts, globally and locally segregating individuals and mobile populations as well as racially territorialising whole continents. Sydney and San Francisco are exemplary sites for this modern maritime geography. Both cities were guarded at their oceanic edges by quarantine stations that doubled and tripled in complex ways, as sites of military defence and immigration restriction.

The landscapes of Angel Island and North Head are distinguished by significant mark-making practices arising from their interconnected quarantine, immigration, defence, and leisure uses. In cement and stone, on interior and exterior walls, on paths, trees, and cliff-faces, these prominent marks asserted people's presence - passing moments in time - and simultaneously functioned as messages, postcards to the future. ${ }^{23}$ While some comprise corporate marks - a shipping company, a vessel, a family group - others are highly personal and individualised.

At the Quarantine Station, North Head, there are approximately 1600 inscriptions carved into, or painted onto, the soft and golden sandstone from which the nineteenth-century city was built. First used to isolate incoming passengers in 1828, from 1832 a large sector of the North Head peninsula was reserved for maritime quarantine use until 1984. For most of this history, immigrants, merchants or crew would be diverted to Sydney's quarantine station only if disease was suspected or declared aboard their vessel. From the late 1870s, intermittent disease outbreaks in the 
city of Sydney also saw residents removed and quarantined at North Head, sometimes by force. ${ }^{24}$ Much of North Head became a military reserve in the 1930s, with the Quarantine Station sequestered for army use over 1914-18 and again through 193945.

While it was never a generic immigration screening or processing station akin to America's Ellis or Angel Islands, from the late 1950s the North Head Quarantine Station was used as temporary accommodation for refugees and illegal entrants. In 1984 the now-defunct facility was entrusted to the (state-level) New South Wales National Parks and Wildlife Service, and in 2006 was leased to the private heritage tourism company, Mawland, for adaptive re-use as a heritage-themed hotel and conference centre rebranded as the 'Q Station'.

A significant element of North Head's heritage landscape inheres in its almost unique assemblage of quarantine inscriptions spanning 150 years. Dating from 1835 , they primarily consist of named individuals, vessels and events. These inscriptions abound in the external landscape, turning natural cliff faces into walls of messages and sculptural memorials. Some are formalised mementoes of ships' journeys and the arrival of vessels into quarantine. They name captains, significant crew, and often the ship-board mason who crafted the inscription. Others mark the work of individuals, recording their own names and perhaps their family or children who may have died en route, or at the Quarantine Station. In this sense, they are akin to memorial plaques, commemorating an individual or family [Figures 1 and 2]. The inscriptions include anonymised jokes ('In loving memory of Irish stew'), and even proposals of marriage ('Rebecca will you marry me'). ${ }^{25}$ Most of this mark-making was a public practice undertaken in an external - if perhaps solitary - environment, not an internal architectural one. While most are textual, a few are symbolic - masonic dividers, a 
Maori tiki, a star of David, ropes and anchors, life buoys and shipping company pennants. Of the textual inscriptions most are in English, but others are written in Greek, Cyrillic, Japanese, Arabic and Indonesian, testament to the highly mobile maritime world of the nineteenth and twentieth centuries. Thus they mark Sydney's place as a major port that linked the south-west Pacific to its northern reaches, to the Atlantic and Indian Oceans, and beyond into the Mediterranean and Red Seas. ${ }^{26}$

Figures 1 and 2:

Historic inscriptions at North Head Quarantine Station, Sydney.

One significant group of inscriptions is rendered in Chinese: poems and messages mostly painted onto but sometimes carved into, the soft sandstone. Chinese men quarantined on North Head were as likely to be residents of the city of Sydney, as newcomers to the continent. ${ }^{27}$ When particular diseases were epidemic - smallpox in 1881, for example - Chinese men were removed to North Head irrespective of their contact with a smallpox victim, space, or household, which were the rationales for all other removals. ${ }^{28}$ They were quarantined, in other words, because of their race. Internally, after 1898 they were quarantined again to the so-called Asiatic Quarters, sited below the buildings that accommodated third-class passengers. Other Chinese men detained on North Head were merchants or crew on quarantined vessels, or possibly aspiring immigrants who fitted into the various exceptions written into Australia's immigration act, its 'white Australia' policy. ${ }^{29}$

There are around fifty Chinese inscriptions on North Head. On Angel Island there are thousands; so many, indeed, that they also have not been comprehensively documented. Ceded by Mexico in 1848, its initial value for the new state of California 
was as a second-order defence site. Further fortified by the Union during the Civil War, Angel Island went on to have a minor defence role in the Spanish-American War, and again in the First and Second World Wars. This military use was layered again when a federal quarantine station was established in 1891, followed in 1910 by a purpose-built immigration station.

Modelled on New York's Ellis Island, the facility and staff detained, interviewed, and screened thousands of would-be entrants. San Francisco's Pacific orientation, combined with its nationality-specific federal immigration laws, meant that most of those detained in its two-storey barracks were initially Chinese and later Japanese. The immigration centre was functional until 1940, after which the island reverted to the US Army, housing prisoners of war and enemy aliens during World War II. After the military departed in 1962, Angel Island became a State Park. With the old quarantine buildings bulldozed and burned in 1957, the main tourist focus remains the immigration centre. Rescued from demolition in 1970, the detention barracks are preserved while the old immigration hospital is currently being stripped bare, re-skinned and re-interpreted.

Angel island's immigration station was the location where aspiring Chinese immigrants were interviewed, medically screened and accommodated, sometimes for many months, in the two-storey barracks. It is there - mostly inside the building but also on exterior weatherboards - that remarkable messages, poems, and representations were painted, written, and occasionally carved into, the walls, floor and ceiling in dense clusters. ${ }^{30}$

Figure 3:

Chinese inscription in the Immigration Barracks, Angel Island, San Francisco. 
At one Pacific site - North Head - messages were predominantly crafted in external environments, often featuring the inscribers' identity. Across the ocean, at Angel Island, messages were painted and carved inside an architectural space and almost always remained anonymous. Very few identify either the inscriber or those to whom the message is intended [Figure 3]. The Chinese inscriptions on both sites, however, commemorate and communicate remarkably similar sentiments. An unfinished and undated poem carved onto a slate drain cover at North Head is translated thus:

Trapped on the 'smallpox hill,' a day is like a year

I drink my tears in this sad place, listening to the cuckoo

I ask: When will I find a soul mate?

Looking at the moon, I write poems ...

Remembering the past, I compare it with the present

My homeland is far away, my parents abandoned

For many years they cared for me; yet I have not reciprocated their kindness Barbaric nation(s) ... 31

One compatriot on Angel Island wrote:

I left the village well behind me, bade

Farewell to my father and mother.

Now I gaze at distant clouds and mountains,

Tears forming like pearls. 
The wandering son longed to be wealthy like Taozhu.

Who would have known I would be imprisoned on Island? ${ }^{32}$

At one level, the poems and messages form part of the common phenomenon of prison and asylum graffiti, the quotidian practice of writing on the walls of one's place of detention. ${ }^{33}$ At another level they form part of a particular Chinese poetic tradition that travelled diasporically with merchants, mariners, and migrants, finding new media, contexts, and substance in which to materialize this reverential referencing of literary and cultural tropes.

Analysed within geographies of commemoration, the particular conventions of Chinese poetry are significant. Affect is commonly expressed through landscape features, and, conversely, landscape is folded into feeling. Thus abstract ideas and emotions are conveyed through the association of elements within and between characters: 'loneliness', for example, may be expressed associatively through the character for 'autumn', 'dusk', or 'ocean'. Features of the natural landscape come to represent inner terrain, with natural scenes both reflecting and expressing the poet's affective state. ${ }^{34}$ One verse from Angel Island reads:

In the quiet of the night, I heard, faintly, the whistling of wind.

The forms and shadows saddened me; upon seeing the landscape, I composed a poem. The floating clouds, the fog, darken the sky. The moon shines faintly as the insects chirp. Grief and bitterness entwined are heaven sent. 
The sad person sits alone, leaning by a window. ${ }^{35}$

Much of the Chinese poetry on both sites communicates an act of memory: recall of classical texts and literary forms; remembering other times and elsewhere; the memory of distant homes and kin; feelings of loneliness and of the inability to fulfil duties and responsibilities; anger at forced submission to detention and inactivity; and anxiety about uncertain futures. The Chinese inscriptions bring together affect, memory, and landscape features, and in turn became themselves part of a landscape of memory and commemoration [Figure 4].

Figure 4:

Chinese inscription, Quarantine Station, North Head.

\section{STATE COMMEMORATION ON ANGEL ISLAND: AFFECTIVE}

\section{MEMORIALISATION}

State Park interpretation at the Angel Island immigrant barracks ensures that visitors recognise that would-be migrants of other nationalities were also detained over the years, and that they too contributed to the assemblage of marks. Indeed, as geographer Gareth Hoskins has delineated, this inclusiveness was a precondition of the site's elevation from 'a local place of pain and shame in the shadows of popular consciousness to a National Landmark where self-affirming cries of injustice would extend to all peoples of the United States oppressed on account of their race'. ${ }^{36}$ Angel Island performs a patriotic duty precisely by widening the trauma of the immigration experience and thus recapitulating the exquisite desirability of American citizenship. 
Nonetheless, it was the Chinese history in particular, coupled with the material mass of individual Chinese inscriptions inside the Angel Island immigration barracks, that prompted the successful conservation of the site, including its transfer to State Parks and the halting of demolition plans in $1976 .{ }^{37}$ It is the history of Chinese immigration to the United States, and the sequence of immigration restriction acts and policies, that most defines the island's heritage status, meaning, and value. It was, accordingly, San Francisco's later Chinese-American community who drove more recent mark-making on the island in the form of official commemoration. Yet this progression needs to be read as another layer of marks, albeit in a different register, that holds a conversation with the originals, urging a heightened affective response. This time, however, the affect is state-directed.

Campaigns to conserve, preserve or reserve Angel Island were figured in terms of marking America's multiracial past, but also to maintain the immigration detention buildings as a 'site of conscience'. ${ }^{38}$ The phrase is telling. When Angel Island's custodians became signatories to the International Coalition of Historic Site Museums of Conscience in 1999, their message was scaled from the national to the global; 'detainees' feelings of frustration, sadness and injustice towards exclusion [were] added to the milieu of other issues that include anti-Semitism, genocide, forced movement and economic exploitation'. ${ }^{39}$ The inclusion of an American immigration station on an overt continuum with Holocaust memorials performs both political and affective work.

The story of the barrack's rescue from demolition is itself now formalised as part of the history of the site, retold as one of resistance. Alexander Weiss, a Jewish refugee park ranger and sometime Freedom Rider in Mississippi, saw the inscriptions in the building about to be demolished. Over 1970 he mobilised protests that included 
students and faculty at the San Francisco State College Asian American Studies Department, newly establishing an ethnic studies curriculum. This politicisation immediately followed, significantly, a year-long Indian occupation of nearby Alcatraz Island in 1969. This occupation was also declared via graffiti, including the massive 'You are on Indian Land' messages that themselves became part of San Francisco Bay's heritage of freedom and unfreedom. ${ }^{40}$ Weiss explained: 'We don't have exclusion laws anymore, but we could have them in an instant tomorrow. It could easily happen to some other group of people. That's why we need memorials like concentration camps and Angel Island, so that we will learn from our past and not repeat the same mistakes. ${ }^{41}$ Angel Island was thus situated within the post-war project of active public memorialising of trauma, for the purposes of racial and civic justice. Paradoxically, it also became the place where families marked and celebrated American 'freedom' [Figure 5].

Figure 5:

American Freedom: Angel Island memorialising.

Quarantine stations, immigration detention centres, and concentration camps are often linked. Unmistakably part of the same modern carceral archipelago, they are nonetheless perhaps too often conflated. ${ }^{42}$ Concentration camps and Holocaust memorials linger in the moral geographies of both Angel Island and North Head, although in more and less explicit ways. At the North Head Quarantine Station, the renovation and display of industrial-scale fumigation complexes and shower blocks where newly arrived detainees were required to pass from dirty to clean status, via carbolic showers, often recall concentration camps, although there is no formal 
interpretation to that effect. If visitors seek a darker past for the Quarantine Station than its actual history can necessarily provide, they are compensated, perhaps, by popular ghost tours whose highlight is the hospital's morgue. ${ }^{43}$ This morbid fascination is not an unreasonable response, especially since the Wharf precinct of the quarantine station was - and remains - arranged around seaborne arrival and processing. Upon landing, detainees were separated from their luggage for fumigation, while they were processed through disinfectant showers and sorted into categories that were spatially inscribed and organised: infected men; infected women; non-infected men and women, by first, second and steerage class; Asiatic men.

Angel Island's immigration centre stages a more explicit resonance with concentration camps. This is not necessarily because of the substantive history of immigration detention, but because of the style, spatial arrangement, intertextuality, and intention of the formalised commemorative space. Its touchstone, in short, encompasses both Holocaust memorials and war monuments. In 1979 an obelisk was unveiled: 8 feet high, this 6,000-pound granite monolith was dedicated to Angel Island's Chinese immigration detainees. There was a competition for a poem to be inscribed into the monument, recalling and repeating the verses within the barracks: 'Leaving their homes and villages, they crossed the ocean only to endure confinement in these barracks. Conquering frontiers and barriers, they pioneered a new life by Golden Gate [Figure 6]. ${ }^{44}$ Here both the structure and substance of the informal poems gave the formal, commercially sponsored monument a presence which, Hoskins asserts, 'bestowed the landscape with a new importance ... the potential to confront the politics of racism manifest in federal immigration policy and embodied in the 1882 Chinese Exclusion Act'. ${ }^{45}$ Indeed, whatever solemn tension was implied 
by its massive materiality, the structure was at first legible only to those literate in Chinese.

Figure 6:

Poetic Licence: Angel Island, Immigration Monument.

Into the 1990s, as the Immigration Station transitioned from a community-led avocational enterprise into a National Landmark, the Chinese poems were written across a larger-scale commemorative landscape. In that process, the recent obelisk became problematic, being denigrated to the status of a 'non-contributing' artefact. However much it signified the historicity of the site, the monument itself was rendered out of place - its modernity disrupted the site's carefully curated patina of authentic marginalisation. ${ }^{46}$ The monument has been removed from the immigration precinct and repositioned out of sight on a cliff above the memorial wall. It now overlooks the Bay and perhaps offers a more contemplative space for those visitors who venture up the path to view it. At the same time, in the new memorial space adjoining the foreshore, the visitor experience became increasingly scripted. Brief factual placards and amateur docent spiels were replaced by an inclusive, emotive litany recited by guides. Visitors, Hoskins notes, are now urged to become tremulous immigrants, yearning for the embrace of the nation. ${ }^{47}$

Similarly, the new monument dwells in a landscape of words, drawn from the poems and messages on the interior walls of the barracks: 'HUMAN SPIRIT OPPORTUNITIES - DREAMS - HOPE - FEARS - FAITH - ACCEPTANCE REJECTION - CIVIL RIGHTS - REALITIES - SOCIAL JUSTICE - APPEALS HEARINGS - EXAMINATIONS - DENIAL - PERSEVERANCE - ENTRY' 
[Figure 7]. Engraved in 2010 - in English - these universalising expressions aspire to recontextualise arrival at the station as a point of reflection; not only to learn about injustice, but to feel that injustice.

\section{Figure 7}

Feeling Injustice: Engraved Emotions of Arrival, Angel Island.

Angel Island actively creates a space to remember, and reflect upon, 'wrongs' - wrongs of the past. It is a space inflected by, and drawing upon, a public memory of past public wrong, recalling war memorials most directly. Visitors are invited, indeed almost required, to stop, stand, and contemplate the stone structures with their oversized words and phrases. In the place of textual interpretation or historical explanation, arrivals are asked not just to reflect upon 'fear', 'rejection' or 'perseverance', but to feel them too: it is a re-enactment, of sorts. The very public commemorative landscape aims to elicit profoundly interior contemplation, drawing on the simultaneously private and global resolution 'Never Again'. ${ }^{48}$ This is civic pedagogy through affect; learning through feeling. The cement fabric in which the words are cast is an attempt to reclaim the foundations of these interior spaces. They follow the footprint of the now-absent buildings. Eliciting former architectural spaces, these footings act to 'enclose' the openness of the site, as it remains in the present.

The Angel Island arrival precinct has also borrowed the convention of the 'wall of remembrance', monumental landscapes that build structures out of individual names, marking aggregate or even national suffering from highly personal experience. The 'IMMIGRANT HERITAGE WALL' slices into the Angel Island terrain, echoing the Vietnam Veterans Memorial in Washington DC [Figure 8]. Unlike that landmark, 
however, the Heritage Wall is not an exhaustive list of names; rather, it is a space for rent. Sponsors can add their (often bilingual) plaques for a fee, embodying another national narrative: economic prosperity. The public story of Angel Island - unlike any intertextual reference to Holocaust memorials - is finally one of American civic hope and possibility.

Figure 8:

Prosperous arrival: Immigrant Heritage Wall, Angel Island.

The re-use of Chinese immigrants' inscriptions shifts earlier unauthorised mark-making into official, highly designed, instrumental state commemoration. Ironically, the diffuse invocation of injustice sacralises the site's moral geography, projecting a gravitas redolent of the imposing façade once faced by immigrants. By co-opting century-old protests into a reverent national story, counter-narratives are rendered both disrespectful and unpatriotic. No modern graffiti appears in the grounds; none is permissible inside, where it might overwrite, taint or reanimate the original immigrant inscriptions. ${ }^{49}$ Instead, small votive offerings of local rocks and dimes have accumulated around the cliff-top Immigration Monument, subversive and illicit performative gestures of commemoration and inscription in a landscape where messages are otherwise controlled and managed. There is not even a visitor book where - as Tim Edensor remarked of monuments mobilised for Scottish nationalisms - alternative scripts can be articulated. ${ }^{50}$ Inclusiveness is mandatory.

\section{GRAFFITI RETURNS ON ANGEL ISLAND}


Within such circuits of reference, practice and orchestration, what is it that escapes appropriation? Circularity characterises Angel Island. Its very geography effectively dictates that visitors must traverse all of its sites, whether performing a clockwise or anticlockwise circumnavigation. Either way, tourists are confronted by the historical overlap of its facilities and functions. The US Army Signal Corps installed telephones for quarantine station staff, who in turn conducted trachoma screening of arriving immigrants. ${ }^{51}$ Not all were Chinese: in 1939 , German merchant seamen threatened by a British destroyer were rescued by the USS Tuscaloosa. Transferred from Ellis Island not as enemy aliens but 'guests' of the then-neutral United States, they were accommodated across Angel Island's immigration and quarantine facilities. Informed that their stay would be 'like a summer resort', some even watched movies in the US Army drill hall at Fort McDowell. ${ }^{52}$ Others left their own stamp on the facilities, such as an ironic message left above a doorway in the immigration barracks: 'Türé zu!' (door to!).

Although modern graffiti is not tolerated in the immigration site, it does appear elsewhere on the island. Indeed, every location on Angel Island opens a door to the flow of practices and referents between its sites of memorialisation, leisure and neglect. Ostensibly quarantined behind a collapsing wire-mesh fence, the former Nike missile site (operational 1954-62) remains remarkably unmarked, a solitary faded tag embellishing an electrical switchbox. A sprayed skunk stencil ruptures the rusticity of the dilapidated third hospital at Camp Reynolds, one of the few locations where graffiti is actively, if not systematically, overpainted. Across the island, Fort McDowell stands on a site once used to detain military returnees from the Philippines, keeping them separate from San Francisco in case they harboured disease, and from outbound recruits lest their ardour be dampened. Ironically, its hospital now appears 
to have been shelled by artillery, sitting gutted and shattered in contrast to the carefully maintained administration block and officers' quarters nearby. The interior walls of the Fort's structures are now riddled with contemporary graffiti, perhaps in response to the constraint required in the adjacent immigration centre.

In the absence of interpretive signage at Fort McDowell's former hospital, visitors instead encounter a pencilled poem, viewed via a hole torn through its walls. In lettering increasing in size and ferocity from eye-level to knee-high, it reads [Figure 9]:

FROM NOW ON, I AM DEPARTING FAR FROM THIS BUILDING

ALL OF MY FELLOW VILLAGERS ARE REJOICING (IN)

W WITH ME

DON'T SAY THAT EVERYTHING WITHIN

IS WESTERN STYLED

(EVEN IF) IT IS BUILT OF JADE

IT HAS TURNED

INTO A CAGE

Figure 9:

Fort McDowell Hospital ruins, Angel Island.

Although impressive, this verse is far from original. As a smeared pencil scrawl nearby explains, it is a translation of the most prominent inscription on Angel Island. ${ }^{53}$ Carved into the walls of the men's immigration barracks, the original Chinese poem is not primarily a protest against detention within an American facility. 
Rather, it decries anti-Chinese racial exclusion enforced by Mexico after $1921 .^{54}$ The very same poem has been laser-scanned and replicated via 3D printing onto a commemorative panel located in the centre of the carefully preserved barracks [Figure 3]. This facsimile is accompanied by its own formal sign asserting that 'You may touch this reproduction, but the historical carvings on the walls are fragile and should not be touched'.

At once appropriated and authorised, yet concurrently generating its own informal conversations, this plaintive verse transcends the nominal divisions of Angel Island's medical, military and migrant pasts. As occurs in many of the island's former coastal artillery bunkers, visitors seek their own spaces for expression and engagement with contemporary and future visitors. These vernacular commemorative processes, which feed upon formal messages but resist their overdetermination, are reminiscent of similar sites of public commemoration of celebrities such as Princess Diana's crash site in Paris or the fans of Elvis Presley who pen messages onto the walls outside his mansion. According to geographer Derek Alderman, this is a sanctifying - rather than sacrilegious - act: 'making the pilgrimage to Graceland is about being an author of Elvis' memory rather than simply a consumer of it' ${ }^{55}$

Indeed, informal or semi-formal graffiti production need not entail a 'battlefield' contest between such authors and the authorising structures of legislation, surveillance and effacement. The ongoing historical, highly visible and often labourintensive assemblage of inscriptions at the North Head Quarantine Station bears witness to the possibilities of a vernacular 'gallery' receiving formal endorsement. ${ }^{56}$ Indeed, as is the case at both North Head and within the Angel Island immigration barracks, the perceived historicity of such traditions-in-place has seen them subsumed 
into the commemorative landscape, protected in turn from official or malicious destruction.

Historicisation appears to be the key, however. Whether in Angel Island's Chinese poetry or on segments of the former Berlin Wall, informal inscriptions may become permissible within a national interpretive framework when they can be repackaged to facilitate national redemption of a shameful past. ${ }^{57}$ Rather different operations come into play when the continuity of unauthorised mark-making intersects with a shameful present.

\section{DEPORTATION: IMMIGRANTS' GRAFFITI ON NORTH HEAD}

While parts of Angel Island sat ambiguously between military, immigration, and quarantine use, so the Quarantine Station at North Head became an immigration station of sorts in the 1960s. In that decade, and until 1984, the site was intermittently used to accommodate entrants both legal and illegal. For instance, the Quarantine Station housed refugees arriving in Australia from the so-called Operation Babylift in April 1975. Vietnamese infants and children flown to Sydney were accommodated and cared for at North Head until placed with their new foster families. Photographs of the smiling children, newly 'Australian', were taken in front of the old sandstone inscriptions, the marks of former occupants who came to Australia's edge in entirely different circumstances. ${ }^{58}$

The other late-twentieth century 'immigration' use of the Quarantine Station site was exclusionary rather than inclusionary. From 1959 until 1976 it served as a place of detention for unauthorised entrants awaiting deportation and repatriation. ${ }^{59}$ Eastern European, Turkish, Tongan, Fijian, Indian, Chinese, Indonesian and Timorese men left a rich graffiti record on the walls of the secured building (A20) in which they 
were housed. Although most of the graffiti occurs on the internal walls of the building, like the Barracks at Angel Island some faint marks also occur on the external masonry walls. Peaking over the period 1973-76, the pencil, biro, felt-tip pen and scraffito marks are mostly names, dates and places of origin. Like those at Angel Island, some are figurative and some are poetic, albeit reduced in formality and complexity. A couplet dated to 1976, for example, reads: 'Life is full of heartbreaks / The sea of love is full of turmoil'. Another is prose, similarly written onto a wall in ballpoint pen, likely from the same year:

Hong Kong. Alas, I .... flew across oceans and went to Australia. Despite my talents, my courage, resilience and wit, I was betrayed by my landlord. But I could not get out of it. My loyalty to my friends had me trapped: I was caught. Life is like the weather: there are better days and there are worse. No one can foresee when failure will come. The hit was painful. However, failure begets success. In an ideal world, I would never feel satisfied until I have left behind this hard-to-live-in world. There are reasons for my pride: I am well-versed in the arts and martial arts. I can speak Mandarin, Cantonese, English and French. I have practised eight years of martial arts. Unfortunately..... I am too kind and a man of my word. ${ }^{60}$

Others are poems of a different kind. A Javanese deportee was resigned; forgiving rather than resentful of Australian authorities carrying out their duty. His Indonesian lines gestured to 'IMMIGRATION' in both the substance and the form of this acrostic graffiti [Figure 10]. 
Figure 10:

Graffiti in Building A20, Quarantine Station, Sydney.

I was very bad luck mate [I was very unlucky]

Late at night came home from work

It was people in suits

Because my visa was expired

They all took part in arresting me

What could I say if that was what fate had in store

God is the one who decides all that

Immigration [is] just carrying out its duty

Okay then going home it is

Later I swap my amulet and come back again if I can. ${ }^{61}$

Much of this immigration-centred graffiti on North Head is commonplace and vernacular, including sexual messages, names and dates, and identification with places of origin and presumably reluctant return. One image depicts an aeroplane with deportee waving cheerfully from a window, a reminder that the world had moved on from maritime and oceanic geographies to the compressed time and space of air travel, in the process radically re-ordering the border geographies of island-nations such as Australia. This is a self-portrait of sorts, the detainee looking poignantly back at himself, as well as new arrivals.

The detainees who wrote and drew on the walls of their barracks on North Head, much as the Chinese had on Angel Island earlier in the twentieth century, imagined future observers also in detention. If their messages also comprised an 
informal conversation between texts, it is unlikely that they imagined their traces being commemorated by any official authority, still less the very state that held them in these places of isolation. In the case of Angel Island, they would be wrong; but in the case of North Head, they would only be partially correct. At North Head the acknowledgement of these mark-making activities is more subtle, a function perhaps of the adaptive re-use of the building as a function centre for corporate conferences and weddings. There is one small interpretive sign at the entrance to A20 contextualising the graffiti and some high-school groups are shown examples during tours. Most of the immigration graffiti, however, passes without any interpretive comment and certainly no commemoration. Unlike the Chinese poems at Angel Island, this graffiti has remained authentic, as it were, unauthorised, uninterpreted, and uncommemorated. Many traces of individual messages are now peeling and fading on interior walls.

Far from being incorporated into the North Head story, let alone officially commemorated, this graffiti is actively and expediently hidden. Some of the graffiti was covered in the process of re-working the spaces of the building as public function rooms. All the graffiti in what is now a dining room was painted over, although some significant examples still remain on view in the adjacent public reception area. Some have been preserved under perspex panels, while others remain behind thin gauze curtains, literally veiled to avoid offence. For example, in full view on the wall next to the entrance to A20's dining room, one text reads 'STEVENI SUCK ME IN TOILET IN KING CROSS', name-checking Sydney's red-light district. The majority of the untouched marks however, are removed from public view, located in rooms now repurposed as a wine cellar and storage areas. 
The risk of offence, moreover, is more seriously evident when placed in the amplified context of national stories and histories. This element of immigration detention is rarely recounted as part of North Head's past, and the graffiti itself thus far resists historicising. This is perhaps because immigration detention is as much about the Australian national present as its bygone eras. The arrival and deportation of would-be refugees and immigrants is Australia's enduring premier political matter; the geopolitical and cultural security of the island-nation is ostensibly at stake, immigration policy constantly shifting, even to the extent of 'off-shoring' the actual borders of national territory itself. ${ }^{62}$

\section{INTRUSIVE ASSERTIONS OF AFFECT}

Angel Island, San Francisco and North Head, Sydney are mirror-imaged sites that face each other across the Pacific Ocean. Their historical geographies similarly conflate military and disease threats, immigration and health imperatives, civic pasts of national exclusion and inclusion. Yet it is the sheer profusion of mark-making that links these places as institutional twins, however rare in the modern carceral archipelago. Multiple traditions of materially commemorating presence, marking journeys, and memorialising death and trauma, shape the past and the present of these rich sites into multi-temporal places. With their contemplative words, the stateorchestrated memorials at Angel Island sit somewhere between 'Never Again' and 'Lest We Forget', the travails of immigration thus bleeding into the story of modern war, genocide, and conflict.

Twisting and turning through histories, memories, and commemoration of defence, disease, and immigration, the mark-making on these two sites is exemplary. This is so not just because of its density, but because of the layers, circuits, and 
repetitions of formal and informal, authorised and unauthorised, individualised and state signatures that so insistently tag, stamp, inscribe, and impress the natural and cultural structures. Individual mark-making is of course a practice both ancient and enduring. But in these liminal and coastal 'new world' sites, fledgling national histories were - and clearly still are - at stake. These national histories are as precarious, perhaps, as the tentative entry of a Chinese immigrant to Angel Island, or the peeling graffiti on a detention-centre wall in the Quarantine Station in Sydney. It is no wonder that their official commemorations constitute such an intrusive assertion, over-insistently directing not just thought, but feeling. 


\section{NOTES}

${ }^{1}$ J. Gillis (Ed) Commemorations: the Politics of National Identity, Princeton, 1994; J. Young, The Texture of Memory: Holocaust Memorials and Meaning, New Haven, 1993; A. Huyssen, Present Pasts: Urban Palimpsests and the Politics of Memory, Stanford, 2003. For the evaluation of graffiti as heritage, see L. MacDowall, In praise of 70K: cultural heritage and graffiti style, Continuum 20 (2006) 471-484;

S. Merrill, Keeping it real? Subcultural graffiti, street art, heritage and authenticity, International Journal of Heritage Studies (2015) 21:4, 369-389.

${ }^{2}$ H. Mytum and K. Chapman, The origin of the graveyard headstone: some $17^{\text {th }}$ century examples in Bedfordshire, Church Archaeology 7-9 (2006) 67-78; H. Mytum, Death, burial and commemoration: an archaeological perspective on urban cemeteries, in: A. Green, P. Leech (Eds), Cities in the World, Leeds, 2006.

${ }^{3}$ Y. Hamilakis, Archaeologies and the Senses: Human Experience, Memory, and Affect, Cambridge, 2013.

${ }^{4}$ For instance, E. A. Modlin Jr., D. H. Alderman and G. W. Gentry, Tour guides as creators of empathy: the role of affective inequality in marginalizing the enslaved at plantation house museums', Tourist Studies 11 (2011) 5-9; P. Stone and R. Sharpley, Consuming dark tourism: a thanatological perspective, Annals of Tourism Research 35 (2008) 589-590; V. Plesch, Memory on the wall: graffiti on religious wall paintings, Journal of Medieval and Early Modern Studies 32 (2002) 167-198; J.Santino, Spontaneous Shrines and the Public Memorialisation of 
Death, New York, 2006; J. Sather-Wagstaff, Heritage That Hurts: Tourists in the Memoryscapes of September 11, Walnut Creek, 2011.

${ }^{5}$ O. J. Dwyer, Symbolic accretion and commemoration, Social \& Cultural Geography 5 (2004) 419-435; A. Nayak, Race, affect, and emotion: young people, racism, and graffiti in the postcolonial English suburbs, Environment and Planning A 42 (2010) 2370-2392.

${ }^{6}$ H. Muzaini and B. Yeoh, Memory-making 'from below': rescaling remembrance at the Kranji War Memorial and Cemetery, Singapore, Environment and Planning A 39 (2007) 1288-1305; H. Muzaini, Making memories our own (way): non-state remembrances of the Second World War in Perak, Malaysia, in O. Jones and J. Garde-Hansen (Eds), Geography and Memory: Explorations in Identity, Place and Becoming, Houndmills, 2012, 216-233; H. Muzaini, On the matter of forgetting and 'memory returns', Transactions of the Institute of British Geographers 40 (2015) 102-112.

${ }^{7}$ D.H. Alderman and J. F. J. Inwood, Landscapes of memory and socially just futures, in N. C. Johnson, R. H. Schein and J. Winders (Eds), The Wiley-Blackwell Companion to Cultural Geography, Chichester, 2013, 273; K. Giles and M. Giles, The writing on the wall: the concealed communities of the East Yorkshire horselads, International Journal of Historical Archaeology 11 (2007) 336-357.

${ }^{8}$ R. Rose-Redwood, D. Alderman and M. Azaryahu, Collective memory and the politics of urban space: an introduction, GeoJournal 73 (2008) 161; L. Smith, Theorizing museum and heritage visiting, in A. Witcomb and K. Message (Eds), Museum Theory, Chichester, 2015, 459-461. 
${ }^{9}$ K. E. Till, Artistic and activist memory-work: approaching place-based practice, Memory Studies 1 (2008) 101. See also K. E. Till, Wounded cities: memory-work and a place-based ethics of care, Political Geography 31 (2012) 3-14.

${ }^{10}$ For Angel Island see E. Lee and J. Yung, Angel Island: Immigrant Gateway to America, Oxford, 2010; N. Shah, Contagious Divides: Epidemics and Race in San Francisco's Chinatown, Berkeley, 2001; G. Hoskins and J. F. Maddern, Immigration stations: the regulation and commemoration of mobility at Angel Island, San Francisco and Ellis Island, New York, in: T. Creswell, P. Merriman (Eds) Geographies of Mobilities: Practices, Spaces, Subjects, Farnham, 2011, 151-167; A. Mayne, Guardians at the gate: quarantine and racialism in two Pacific Rim port cities, 1870-1914, Urban History 35 (2008) 255-274. For North Head see J. Foley, In Quarantine: A History of Sydney's Quarantine Station 1828-1984, Kenthurst, 1996; S. Darcy and S. Wearing, Public-private partnerships and contested cultural heritage tourism in national parks: a case study of the stakeholder views of the North Head Quarantine Station (Sydney, Australia), Journal of Heritage Tourism 4 (2009) 181-199.

${ }^{11}$ See A.M. Stern, Buildings, boundaries, and blood: medicalization and nationbuilding on the US-Mexico border, 1910-1930, Hispanic American Historical Review 79 (1999) 41-81; P. Johnson, Quarantined: Life and Death at William Head Station, 1872-1959, Surrey, BC, 2013; H. Deacon (Ed.), The Island: a History of Robben Island, Claremont, 1996.

${ }^{12}$ P. R. Stone, A dark tourism spectrum: towards a typology of death and macabre related tourist sites, attractions and exhibitions, Tourism 54 (2006) 145-60; W. 
Logan and K. Reeves (Eds), Places of Pain and Shame: Dealing with 'Difficult Heritage', New York, 2008; J. Lennon and M. Foley, Dark Tourism: the Attraction of Death and Disaster, London, 2000. For punitive, protective, and therapeutic rationales for isolation, see C. Strange and A. Bashford (Eds), Isolation: Places and Practices of Exclusion, London, 2003.

${ }^{13}$ O. J. Dwyer and D. H. Alderman, Memorial landscapes: analytic questions and metaphors, GeoJournal 73 (2008) 166.

${ }^{14}$ L. McAtackney, Peace maintenance and political messages: the significance of walls during and after the Northern Irish 'Troubles', Journal of Social Archaeology $11(2011) 88$.

${ }^{15}$ Alderman and Inwood, landscapes of memory and socially just futures, 281.

${ }^{16}$ See also Muzaini and Yeoh, Memory-making 'from below', 1301-2; Muzaini, Scale politics, vernacular memory and the preservation of the Green Ridge Battlefield in Kampar, 393.

${ }^{17}$ For multi-temporal inscriptions and memory, see Y. Hamilakis and J. Labanyi, Time, materiality, and the work of memory, History and Memory 20 (2008) 5-17.

${ }^{18}$ S. Schama, Landscape and Memory, London, 1996; J. Hagen, Historic preservation in Nazi Germany: place, memory, and nationalism, Journal of Historical Geography 35 (2009) 690-715.

${ }^{19}$ Y-F. Tuan, Topophilia: a Study of Environmental Perception, Attitudes and Values New York, 1990; K. Hauser, Shadow Sites: Photography, Archaeology, and the British Landscape, 1927-1955, Oxford, 2007, 1. 
${ }^{20}$ See P. Giles, Antipodean America: Australasia, Colonialism, and the Constitution of U.S. Literature, Oxford, 2013. For Hong Kong-California connections, see E. Sinn, Pacific Crossing: California Gold, Chinese Migration, and the Making of Hong Kong, Hong Kong, 2013.

${ }^{21}$ M. Lake and H. Reynolds, Drawing the Global Colour Line, Cambridge, 2008; A. Bashford, Immigration restriction: rethinking period and place from settler colonies to postcolonial nations, Journal of Global History 9 (2014) 26-48. For Californian-Australian comparison see A. Markus, Fear and Hatred: Purifying California and Australia, 1850-1901, Sydney, 1979; D. Goodman, Gold Seeking: Victoria and California in the 1850s, Stanford, 1994.

${ }^{22}$ E. Lee, At America's Gates: Chinese Immigration During the Exclusion Era, 1882 1943, Chapel Hill, 2003; R. Mawani, The island of the unclean: race, colonialism and 'Chinese leprosy' in British Columbia, 1891-1924, Law, Social Justice \& Global Development Journal, 1 2003, online: http://www2.warwick.ac.uk/fac/soc/law/elj/lgd/2003_1/mawani, accessed 30 September 2014; G. Watters, The S.S. Ocean: dealing with boat people in the 1880s, Australian Historical Studies, 33 (2002) 331-343; G. Hoskins and T. Cresswell, Making up Chinese-Americans: moral geographies of immigration in the Chinese Exclusion Act (1882) and The Peopling of America Theme Study Act (2001), in: E. Yiannopoulou, M. Margaroni (Eds), Metaphoricity and the Politics of Mobility, Atlanta, 2006, 69-86. 
${ }^{23}$ A. Clarke, U. Frederick, and A. Williams, "Wish you were here": historic inscriptions from the North Head Quarantine Station, Manly, NSW, Australasian Historical Archaeology 28 (2010) 77-84.

${ }^{24}$ P. H. Curson, Times of Crisis: Epidemics in Sydney, 1788-1900, Sydney, 1985; P. H. Curson and K. McCracken, Plague in Sydney: the Anatomy of an Epidemic, Sydney, 1989.

${ }^{25}$ U. Frederick and A. Clarke, In loving memory: inscriptions, images and imagination at the North Head Quarantine Station, Sydney, Australia, in: I-M. B. Danielsson et al. (Eds), Encountering Imagery: Materialities, Perceptions, Relations, Stockholm, 2012, 51-75; A. Clarke and U. Frederick, "Rebecca will you marry me? Tim": inscriptions as objects of biography at the North Head Quarantine Station, Manly, New South Wales, Archaeology in Oceania 47 (2012) 84-90.

${ }^{26}$ J. Soemarjono, A20 inscription translations from Indonesian, Sydney: National Parks and Wildlife Service NSW, 1986; J. Xia and J. Zhou, Draft Report on translation of the Chinese engravings at the Quarantine Station, Sydney: National Parks and Wildlife Service NSW, 1986.

${ }^{27}$ G. Karskens: Life in Early Sydney, Melbourne, 1997; J. Lydon, Many Inventions: The Chinese in the Rocks, Sydney 1890-1930, Clayton, 1999.

${ }^{28}$ A. Bashford, Imperial Hygiene: a Critical History of Colonialism, Nationalism, and Public Health, Basingstoke, 2004. 
${ }^{29}$ J. Fitzgerald, Big White Lie: Chinese Australians in White Australia, Sydney, 2007;

A. Mayne, "The dreadful scourge": responses to smallpox in Sydney and Melbourne, 1881-2, in: R. M. MacLeod, M.J. Lewis (Eds), Disease, Medicine, and Empire: Perspectives on Western Medicine and the Experience of European Expansion, London, 1988, 223-229.

${ }^{30}$ G. Hoskins, Poetic landscapes of exclusion: Chinese immigration at Angel Island, San Francisco, in: R. Schein (Ed), Race and Landscape in America, New York, 2007, 97-100.

${ }^{31}$ Translation by M. Sin, Report on the Chinese inscriptions at The North Head Quarantine Station, Sydney, November 2013, 19.

${ }^{32}$ H.M. Lai, G. Lim and J. Yung, Island: Poetry and History of Chinese Immigrants on Angel Island, 1910-1940, Seattle, 1991, Poems 43, 92. Reproduced with permission.

${ }^{33}$ E. Casella, Written on the Walls: Inmate Graffiti within Places of Confinement, in A. Beisaw and J. Gibb (Eds), The Archaeology of Institutional Life, Tuscaloosa, 2009

${ }^{34}$ J.J.Y. Liu, The Art of Chinese Poetry, Chicago, 1966; Z. Cai (Ed) How to Read Chinese Poetry: a Guided Anthology, New York, 2008. M. Sin, Report, 19. We are grateful for Maria Sin's insights into, and assistance with analysis of the Chinese poems at North Head.

${ }^{35}$ Poem 13, Random Thoughts Deep at Night, in Li, Lim, and Yung, Island, 52. Reproduced with permission. 
${ }^{36}$ G. Hoskins, A place to remember: scaling the walls of Angel Island Immigration Station, Journal of Historical Geography 30 (2004) 692.

${ }^{37}$ T. Cresswell and G. Hoskins, Place, persistence, and practice: evaluating historical significance at Angel Island, San Francisco, and Maxwell Street, Chicago, Annals of the Association of American Geographers 98 (2008) 392-393.

${ }^{38}$ Lee and Yung, Angel Island, 302.

${ }^{39}$ Hoskins, A place to remember, 697.

${ }^{40}$ C. Strange and T. Loo, Holding the Rock: the 'Indianization' of Alcatraz Island, 1969-1999, The Public Historian 23 (2001) 55-74.

${ }^{41}$ Alexander Weiss, interview, quoted in Lee and Yung, Angel Island, 304.

${ }^{42}$ For analysis of Australian political agitation against immigration centres as 'concentration camps', as well as their links to powers and places of detention in quarantine pasts, see A. Bashford and C. Strange, Asylum-seekers and national histories of detention, Australian Journal of Politics and History 48 (2002) 509527.

${ }^{43}$ Fieldwork observations, The Quarantine Project, University of Sydney, 2013-14.

${ }^{44}$ Poem by Ngoot P. Chinn translated by Lee and Yung, Angel Island, 306.

${ }^{45}$ G. Hoskins, Materialising memory at Angel Island Immigration Station, San Francisco, Environment and Planning A 39 (2007) 447.

${ }^{46}$ Hoskins, Materialising memory at Angel Island Immigration Station, 449-450. 
${ }^{47}$ Hoskins and Maddern, Immigration stations, 162. G. C. Hoskins, Memory and mobility: representing Chinese exclusion at Angel Island Immigration Station, unpublished $\mathrm{PhD}$ thesis: University of Wales Aberystwyth (2005), chapter 6.

${ }^{48}$ The Treblinka memorial reads 'never again' in Polish, Yiddish, Russian, French, English, and German. See Young, The Texture of Memory, 190-192. See also United States Holocaust Memorial Museum, http://neveragain.ushmm.org, accessed 15 September 2014.

${ }^{49}$ In contrast, see T. Moreau and D. H. Alderman, Graffiti heritage: Civil War memory in Virginia, in O. Jones and J. Garde-Hansen (Eds), Geography and Memory: Explorations in Identity, Place and Becoming, Houndmills, 2012, 139160.

${ }^{50}$ T. Edensor, National identity and the politics of memory: remembering Bruce and Wallace in symbolic space, Environment and Planning D: Society and Space 29 (1997) 182.

${ }^{51}$ See for instance, Quarantine Station, Angel Island, California. Letters from the Surgeon General to the Medical Officer in Charge, July 1, 1891 - July 1, 1918, US National Archives, RG90, Box 17, Volume 6: 7 May 1903 to 13 October 1904.

52 J. Soennichsen, Miwoks to Missiles: a History of Angel Island, Tiburon, 2001, 147.

${ }^{53}$ See Hoskins, Poetic landscapes of exclusion, 97.

${ }^{54}$ Lai, Lim, and Yung, Island, 132-135. 
${ }^{55}$ D. H. Alderman, Writing on the Graceland wall: on the importance of authorship in pilgrimage landscapes, Tourism Recreation Research 27 (2002) 29.

${ }^{56}$ A. Crisp, A. Clarke and U. K. Frederick, Battlefield or gallery? A comparative analysis of contemporary mark-making practices in Sydney, Australia Australian Archaeology 78 (2014) 84-92.

${ }^{57}$ R. Bevan, The Destruction of Memory: Architecture and Cultural Warfare, London (2004) 160-163.

${ }^{58}$ See Joshua Forkert, Refugees, orphans and a basket of cats: the politics of Operation Babylift, Journal of Australian Studies, 36 (2012), 427-444.

${ }^{59}$ Carmel Patricia Kelleher, Quarantine Station North Head 1900-1984: a history of place (unpublished PhD thesis: Macquarie University, 2014), 284-314.

${ }^{60}$ Sin, Report, 2013.

${ }^{61}$ Translated by Vannessa Hearman, Department of Indonesian Studies, University of Sydney.

${ }^{62}$ M. Crock and L. Berg, Immigration, Refugees and Forced Migration: Law, Policy and Practice in Australia, Sydney, 2011. 
Vitae

Alison Bashford is Vere Harmsworth Professor of Imperial and Naval History, University of Cambridge, currently writing a colonial history and geography of Malthus's Essay on the Principle of Population. She is continuing her longstanding research on maritime quarantine with colleagues at the University of Sydney.

Dr Peter Hobbins is a historian of science, technology and medicine. His interests focus on the epistemologies and ontologies of science, and in more-than-human histories that encompass landscapes, animals and technologies.

Dr Anne Clarke is an archaeologist with research interests in the archaeology of crosscultural interaction, Indigenous and colonial/settler mark-making practices, the archaeology of ethnographic museum collections and the interpretation and public presentation of heritage.

Dr Ursula K Frederick is an archaeologist and artist whose primary research interests include art, material culture studies and the archaeology and history of cross-cultural exchange. Particular areas of investigation include the arts of Indigenous Australia, contemporary photography and printmedia, and graffiti. 


\section{Acknowledgements:}

We thank the Mawland Group, National Parks and Wildlife Service New South Wales and California State Parks for access to the locations detailed in this paper. We particularly thank Benjamin Fenkell and Casey Lee from California State Parks for their generous guidance at Angel Island, Vannessa Hearman from the Department of Indonesian Studies at the University of Sydney for interpreting Indonesian inscriptions, and Maria Sin from the Centre for the Humanities and Medicine at Hong Kong University for interpreting Chinese inscriptions. Him Mark Lai, Genny Lim and Judy Yung kindly permitted us to reproduce two of their translations of Chinese poetry at Angel Island. We also gratefully acknowledge the Australian Research Council, the Mawland Group and the University of Sydney for the funding of our cross-disciplinary project (LP120200259). None of the funding bodies influenced the formulation, arguments or expression presented in this paper. 

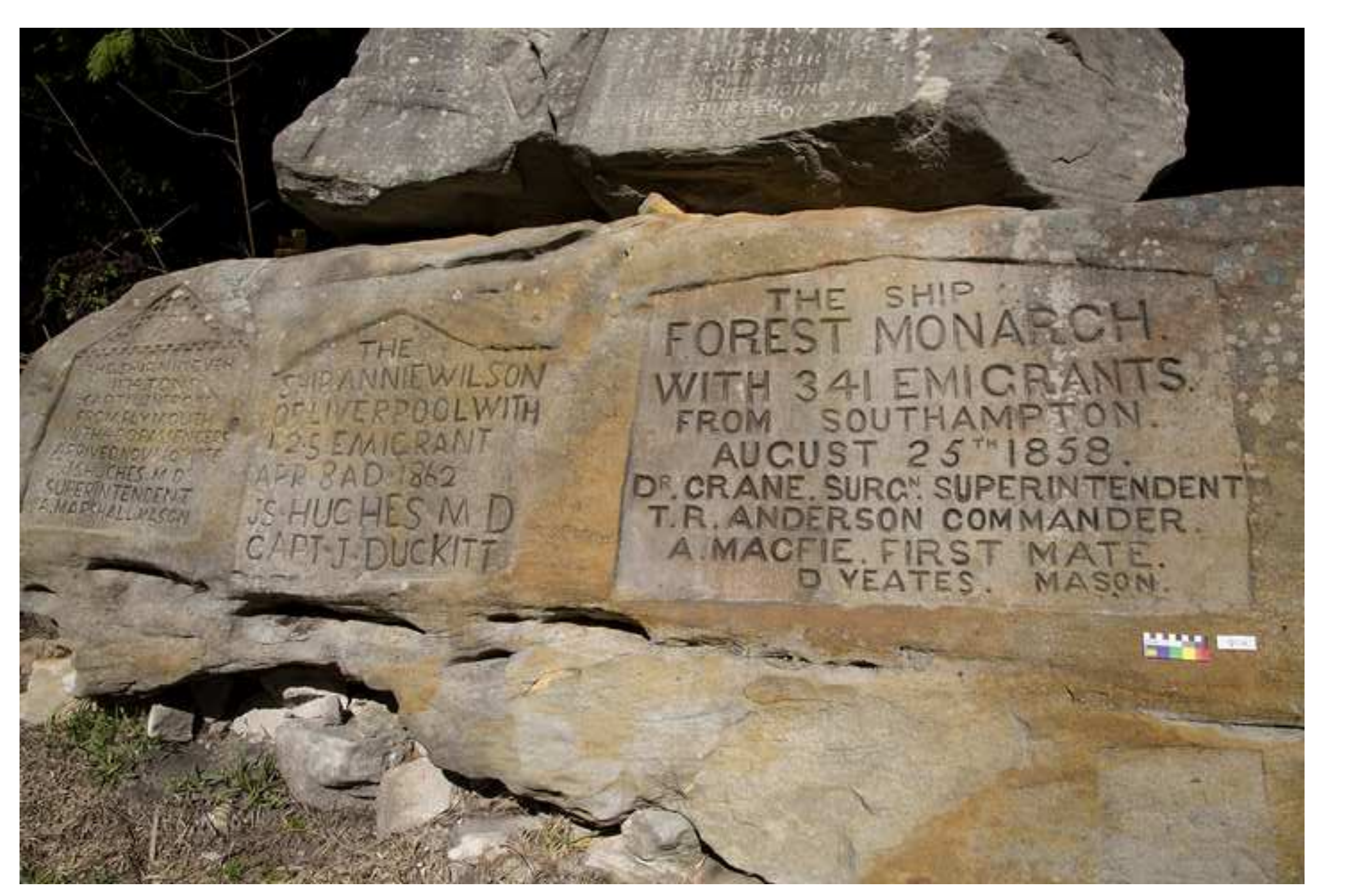

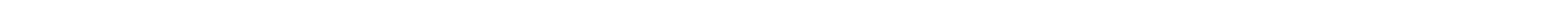




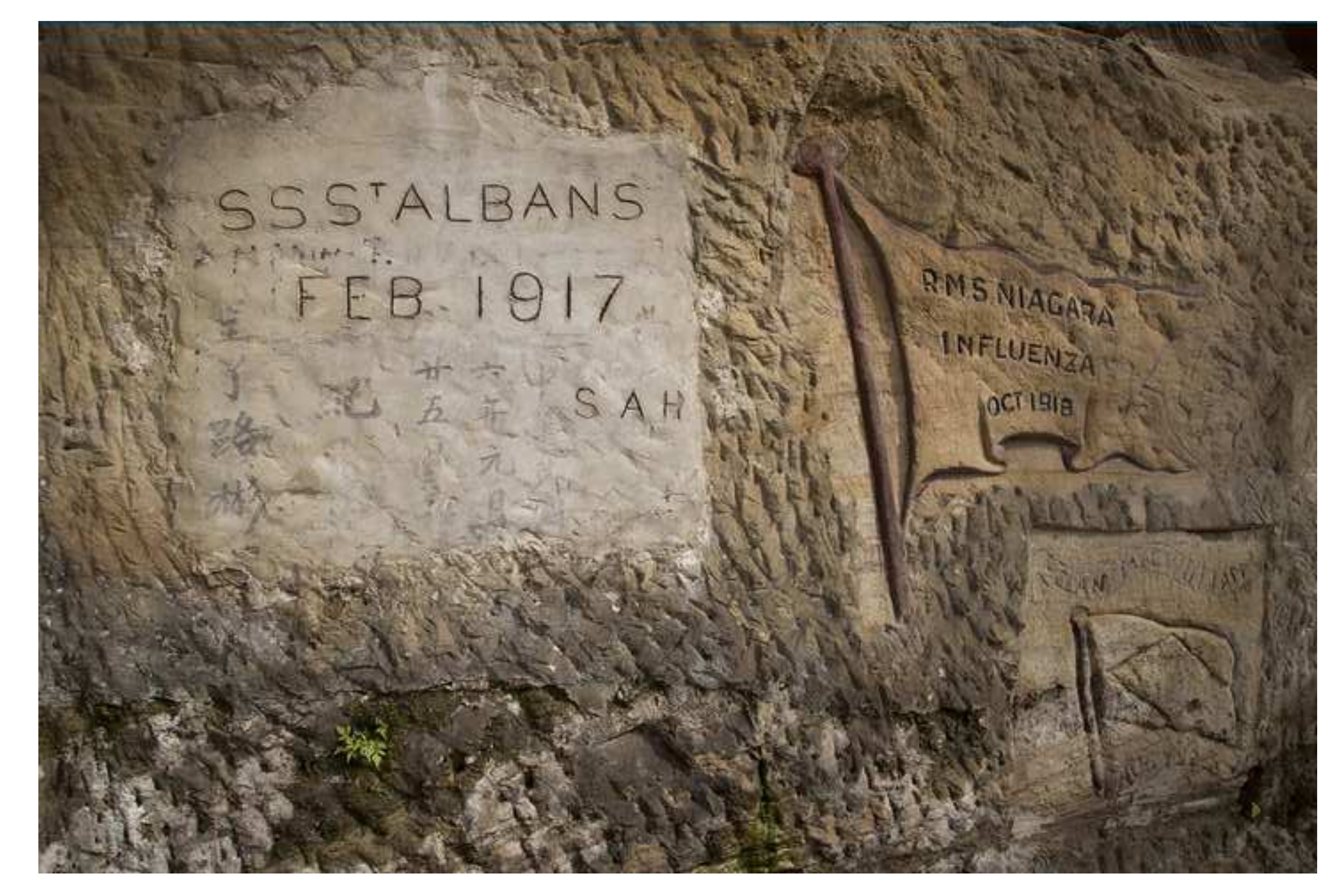

.




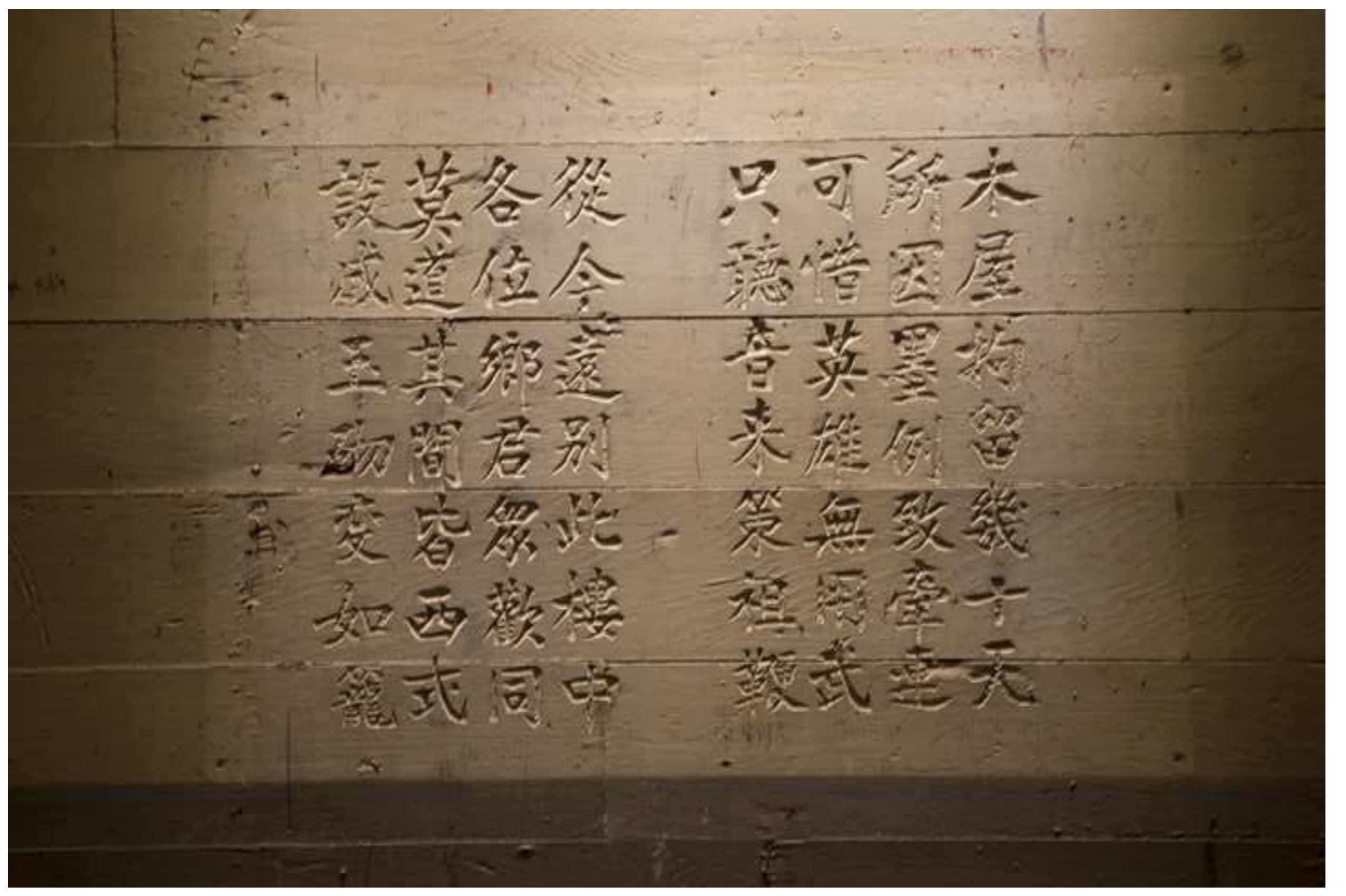


Click here to download high resolution image

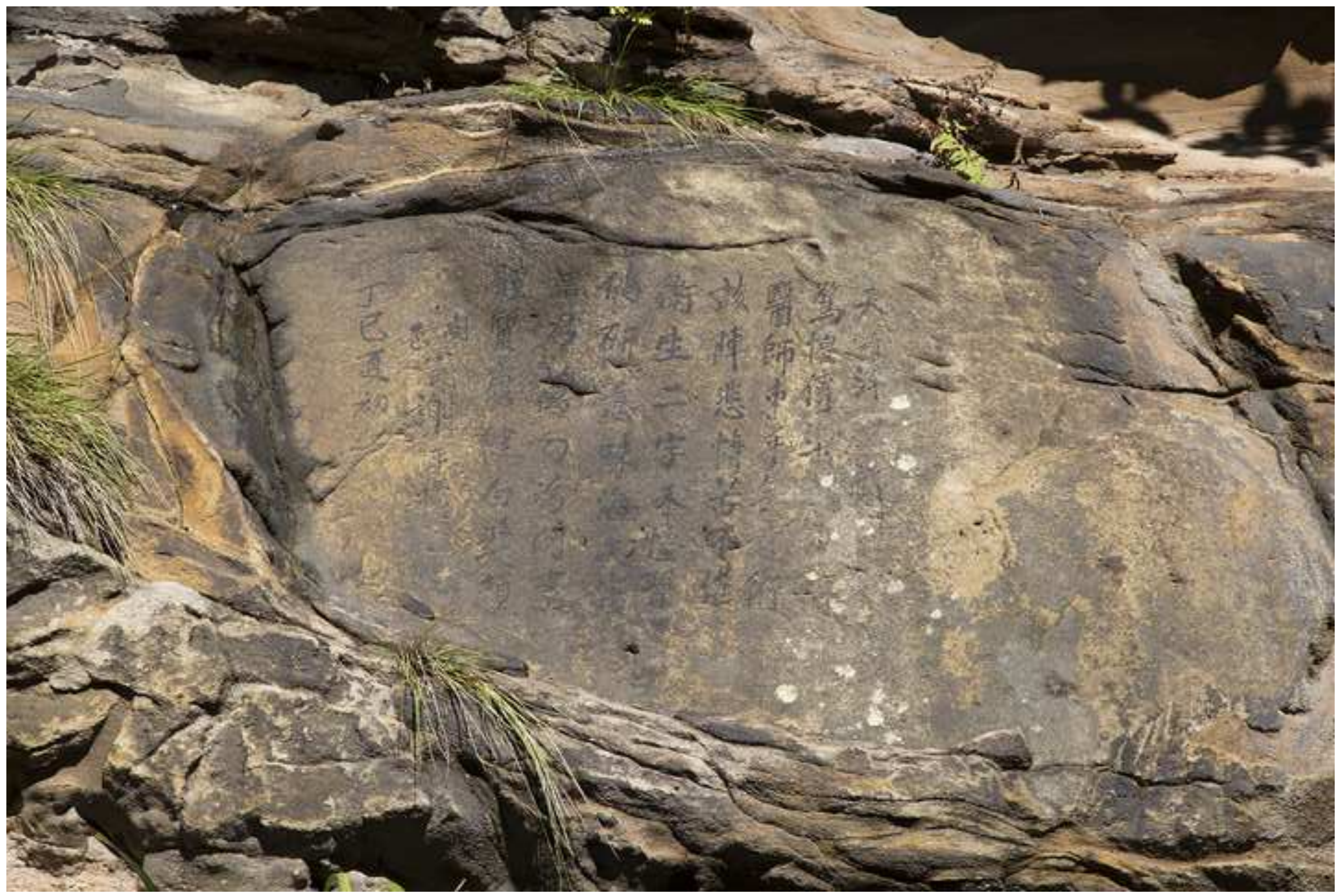




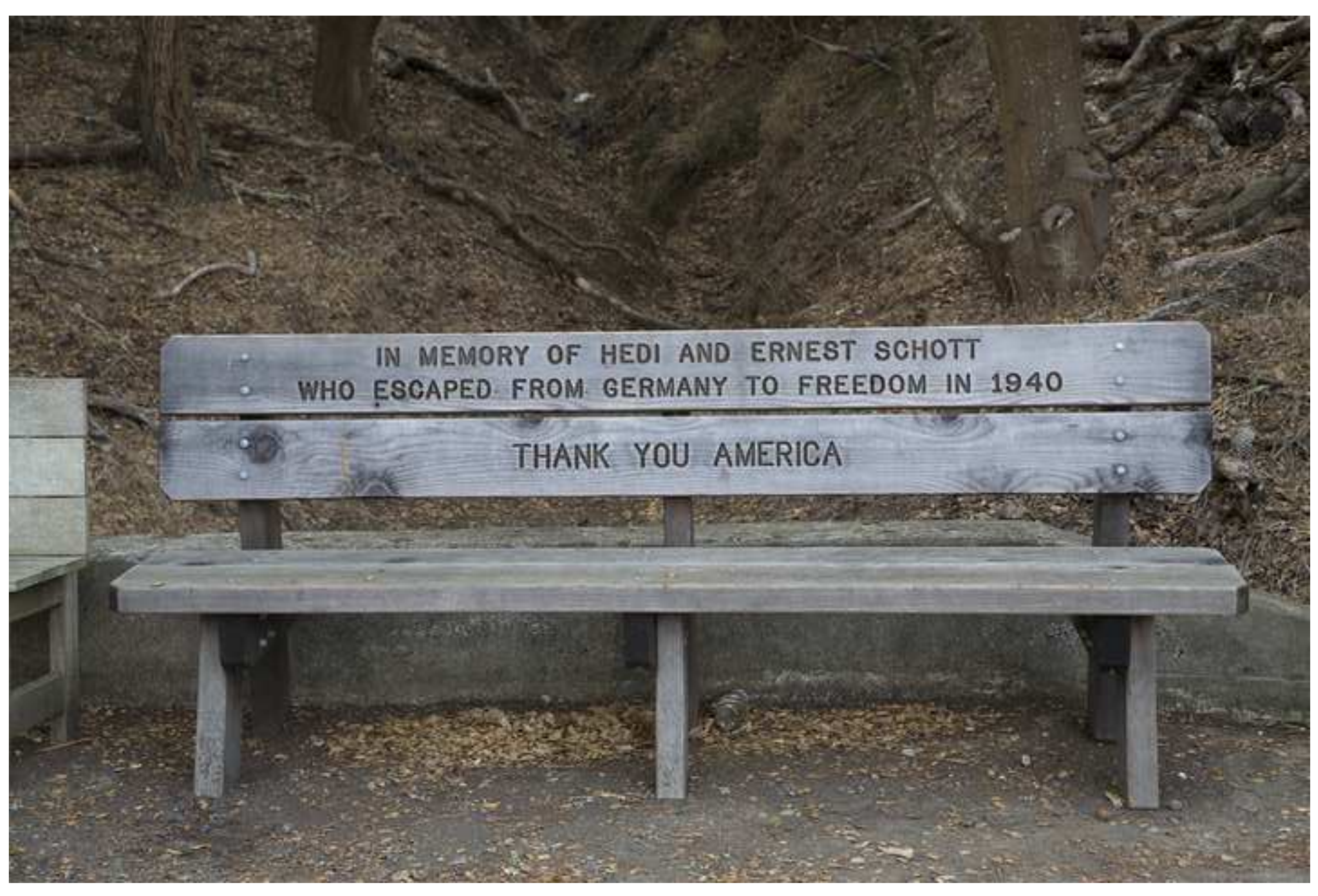


Click here to download high resolution image

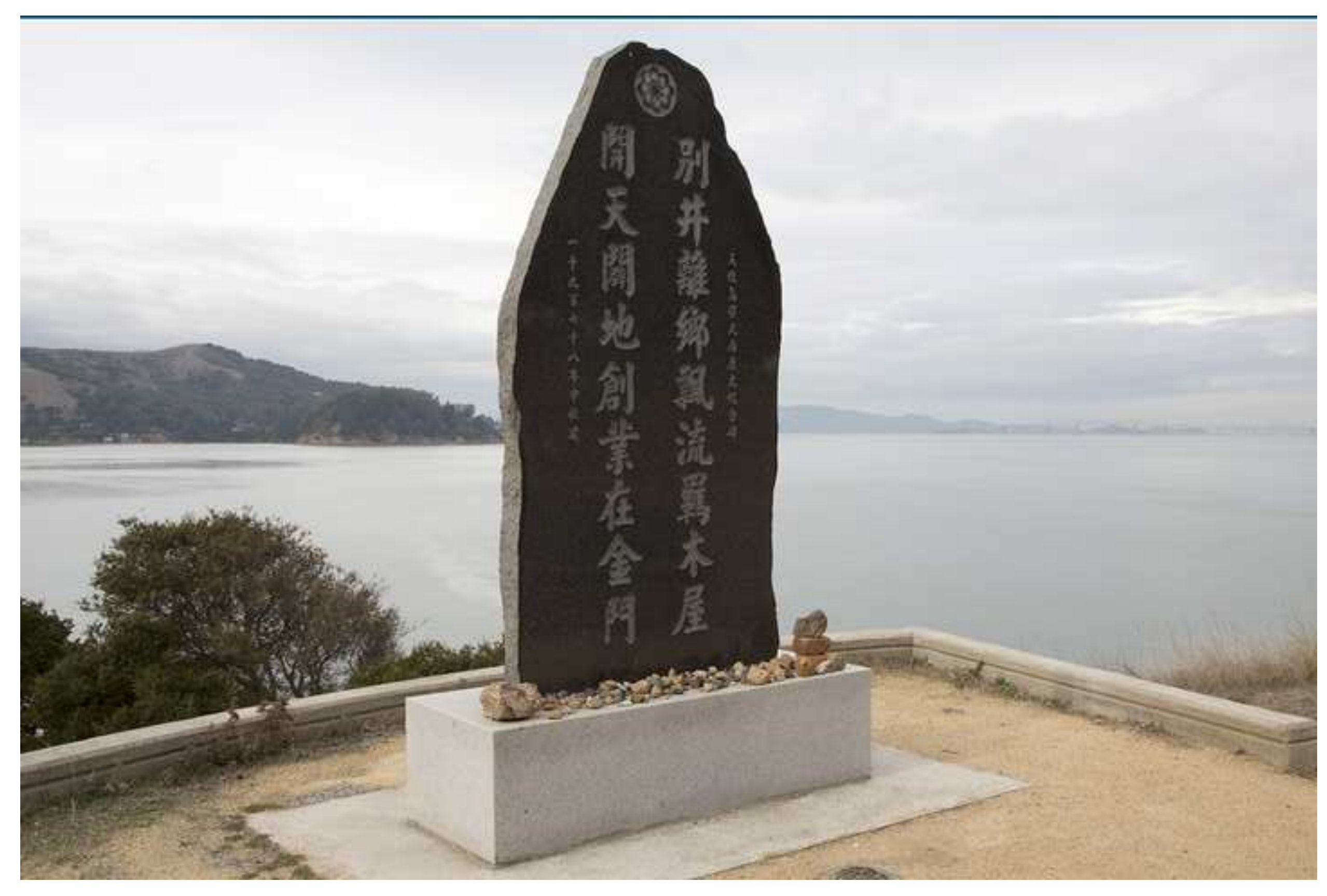


Figure
Click here to download high resolution image

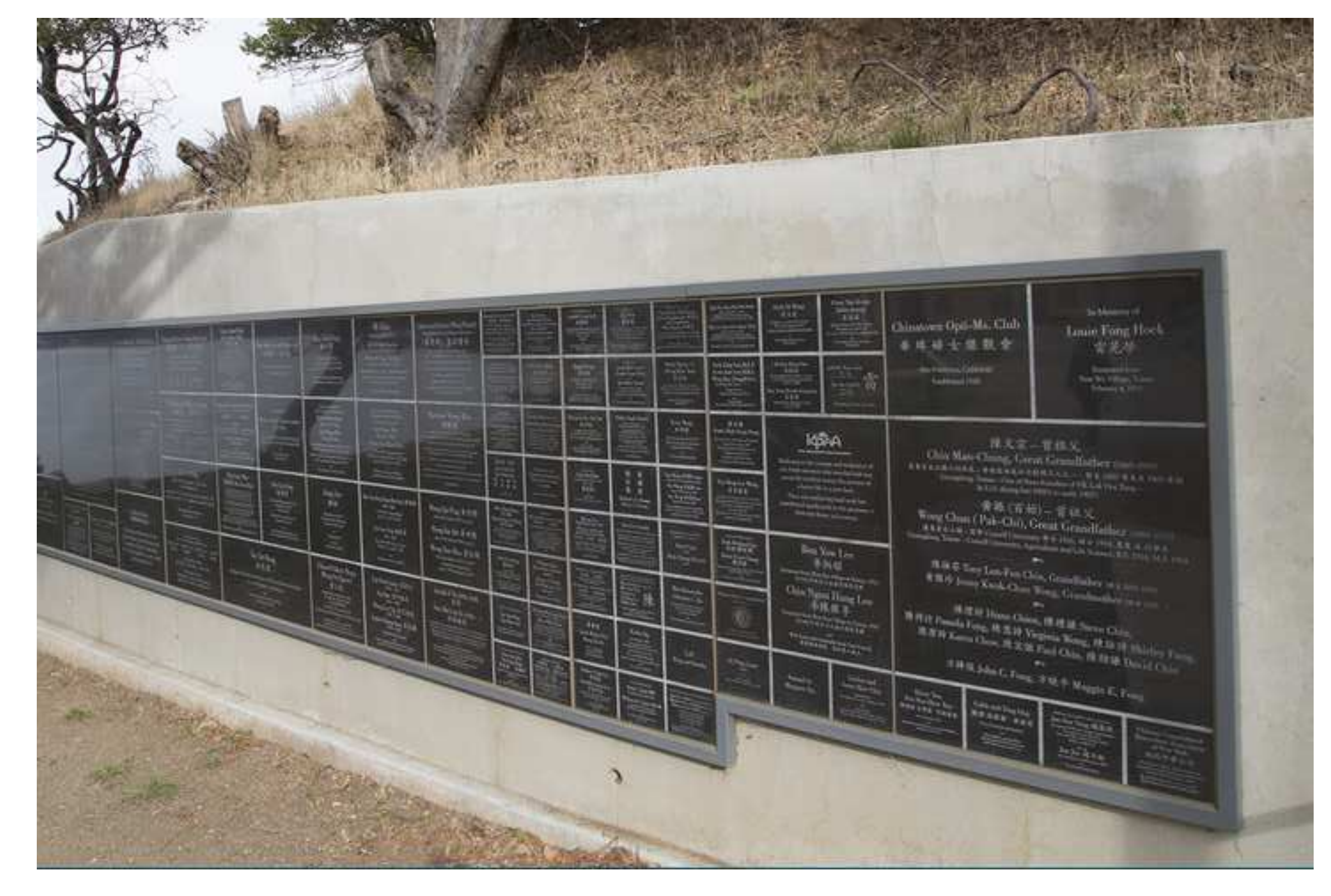


Click here to download high resolution image

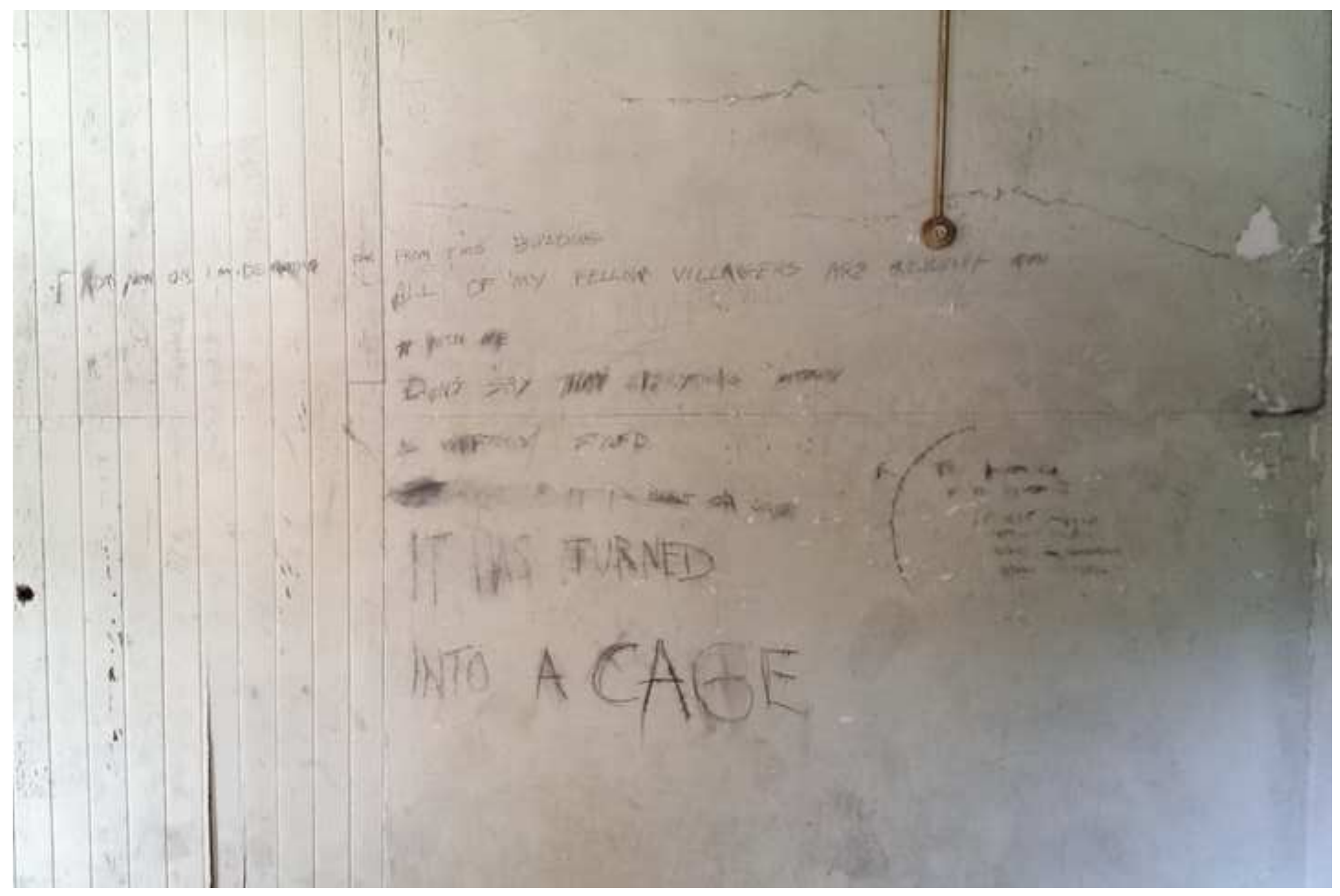


Click here to download high resolution image

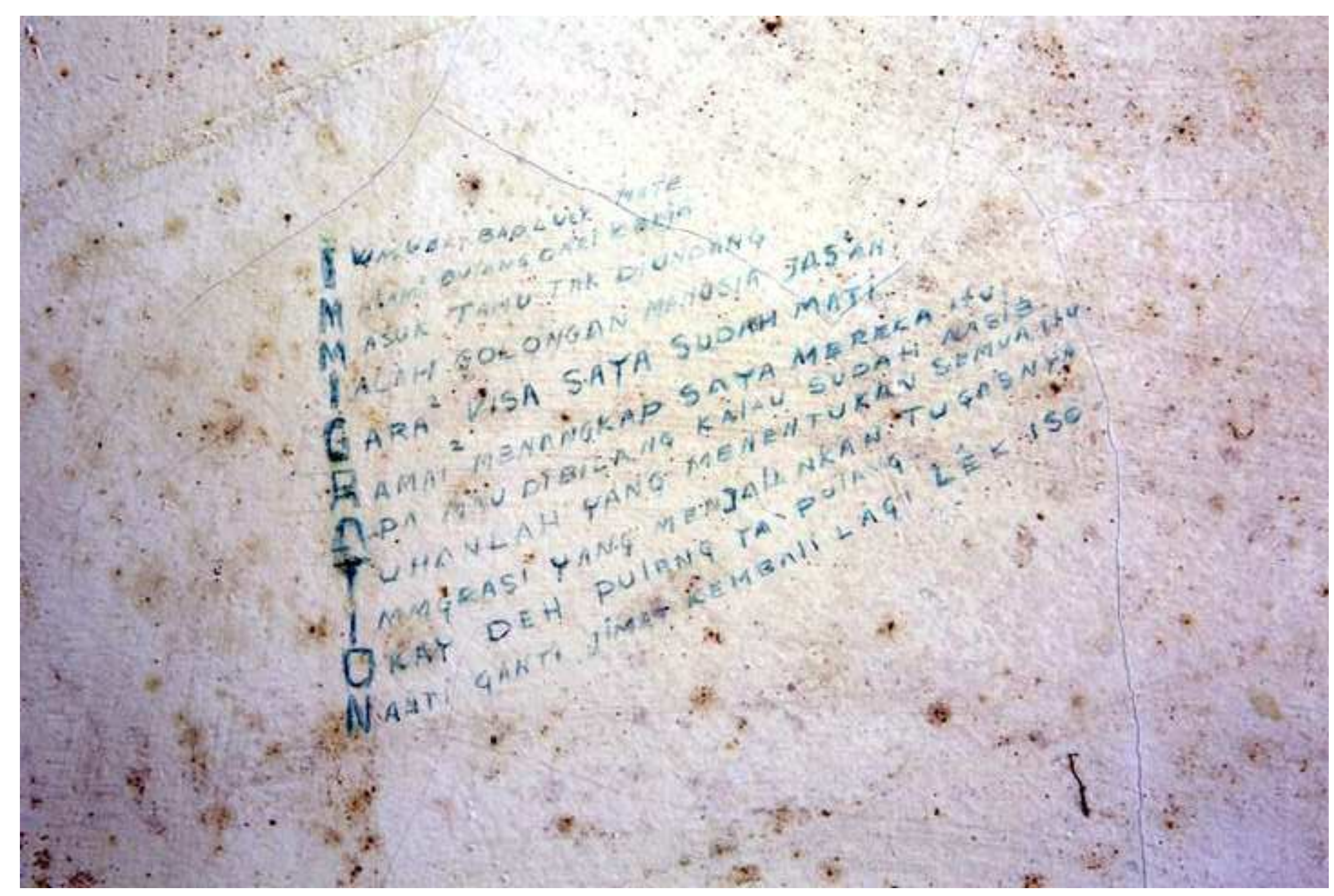

